\title{
PODGORJE U PRIPOVJEDNOMU MODELU VJENCESLAVA NOVAKA
}

Sintija Čuljat

Filozofski fakultet Sveučilišta u Rijeci

Sveučilišna avenija 4

HR 51000 Rijeka

sculjat@ffri.uniri.hr
UDK: 821.163.42.09 Novak, V. Pregledni članak

Ur.: 2016-11-29

Rad obrađuje načine književne artikulacije Podgorja u pripovjednoj prozi Vjenceslava Novaka (Pavao Šegota, Pod Nehajem, Posljednji Stipančići, Tito Dorčić, Dva svijeta). Podgorje nije ubilježeno kao idealizirani zavičajni prostor na rubu Austrijskoga Carstva, već je prometnuto u poetičko sredstvo propitkivanja osobnog i kolektivnog identiteta dionika toga prostora, čiji se marginalni položaj promišlja i kao posljedica konfliktnih i nepostojanih dijelova hrvatske samobitnosti. Pomak u obradi mjesta priče iz središta na rub kao i prijelazi između semantičkih polja velegrada i provincije čine pripovjednu izvedbu kojom Novak obogaćuje svoju realističku poetiku, slikajući razmjere političke i klasne tranzicije u razdijeljenomu, zakutnomu hrvatskomu prostoru, predmetu izvanmatične europske književne proizvodnje. Podjelu na središte i periferiju proisteklu iz razdiobe političke i gospodarske moći devetnaestostoljetne Europe Novak svojom fikcionalnom konfiguracijom prostora poravnava i kao vrijednosnu razdjelnicu. Dvojbe oko pripadnosti izvornome krajoliku čine narativnu strukturu europskoga realističkoga romana na prijelomu devetnaestog i dvadesetoga stoljeća. Pripovjedna topografija Vjenceslava Novaka proširuje hrvatski okoliš krajolikom manjega primorskoga grada i Podvelebitskoga priobalja čijoj izvornoj protežnosti i raznolikosti pridaje značenja izrasla iz napetosti u tumačenju odnosa središta i provincije. Novakovi pripovjedni eskursi o posebnosti Podgorja prepleću se s općim referencijama geopolitičkoga pojma europske provincije što se podjeljuju tomu rubnomu prostoru.

Ključne riječi: Vjenceslav Novak, pripovjedni prostor, Podgorje, poetika, središte, rub

Kakva je semantička valencija Novakova pripovjednoga prostora prema prostoru u djelima njegovih suvremenika i kakva je poveznica Novakove reprezentacije ishodišnoga prostora s procesima oblikovanja identiteta likova njegovih romana i kraćih pripovjednih proza? Od Podgorskih pripovijesti 
(1889) do romana Dva svijeta (1901) i Tito Dorčić (1906), Novak pripovjedno propitkuje granice vlastite terre firme, kao i u hrvatskoj književnosti zaživio romantički koncept pribježišta pred europskim povijesnim prekretnicama i krizama njezinih društvenih ustanova. Takav imagološki koncept ishodi iz europocentrične književnokulturne politike što prepoznaje književnosti "velikih" jezika spram onih s proglašenoga europskoga "ruba".

Novakova pripovjedna perspektiva upućuje upravo na obuhvatni doživljaj preuzeta dvojstva središta i periferije kao određujućega, polaznoga mjesta samobitnosti. Slikanjem neodređenosti, ambivalencije i psihološke izmještenosti svojih protagonista koje slijede iz njihove podvojene protežnosti, Novakov fikcionalni prostor donosi promjenu orijentira $\mathrm{u}$ obradi tema unutar hrvatskoga prostornog imaginarija, pretežito vezanih uz hrvatsko središte Zagreb ${ }^{1}$. Težišnicu svojega prostornoga poretka prema europskim metropolskim odredištima Beču, Pragu, Požunu, Londonu kodira Novak iz zavičajnoga Podgorskoga primorja što nosi predznak onodobne vojnokrajinske te "varmeđijske" ili županijske margine. Rečenim pomakom u predočivanju prostornosti Novak usmjeruje pogled na partikularni krajolik čiji pojmovni i čuvstveni sadržaj postaje sastavnicom hrvatskog identiteta izvan cjeline označujućih geografskih poredaka.

Promjena paradigme prostora kroz postupak umjetničkoga preoblikovanja u suprotnosti je s geopolitičkom podijeljenosti devetnaestostoljetne Europe. Europske diskurzivne prakse i vrijednosni modeli društvenosti reduciraju hrvatski prostor kao mjesto zbiljske pripadnosti ili identitetsko uporište. Novak ustraje u proširivanju europocentričnih koncepata teritorijalnosti, to jest fiksiranih reprezentacija prostora u europskome kulturnome krugu otkrivajući Podgorje kao povijesni i kulturni međuprostor s vlastitim etosom, kao zasebni hrvatski "spacijalni imaginarij" što ga Grgas definira kao "...onaj dio svijeta koji pojedinac ili kolektivitet izdvajaju iz protežnosti i na kojemu uprizoruju i žive partikularnu egzistenciju (...) kognitivno-afektivni okvir pojedinca i kolektiviteta konstruiran pomoću proživljenih iskustava, percepcije i spoznaje..."2.

Novak utvrđuje Senj i Podgorje svojom retoričkom konstantom u pripovjednoj gesti protiv ideologiziranoga diskursa u kojemu se pojam "malenosti" obesnažuje do te mjere da ga je moguće svesti na pojam "atopičnoga mjesta"3, zamišljene orijentacijske točke u psihogramu pripovjednih likova.

\footnotetext{
${ }^{1}$ I. FRANGEŠ, 1978, 386.

${ }^{2}$ S. GRGAS, 2014, 52.

${ }^{3}$ J. HILLIS MILLER, 1995, 7.
} 
On će kontinuirano graditi pripovjedni svijet s vidljivim rascjepom između prostorno i tradicijski mnogolikoga Podgorskog uzmorja i slike o tomu prostoru stvorene od onih njegovih obilježja što su se kroz procese povijesnoga preispisivanja izdvojile iz registra kolonijalnih geopolitika, kakvi su primjerice predznaci "lokalnog" i "drugorednoga" za dijelove "teritorija" kojima se upravlja iz središta moći. Može se reći da Novak prevrednuje i vlastiti položaj pisca europske "drugosti" kada svoju pripovjednu aksiologiju odmjerava prema stilotvornim načelima kritičkoga realizma u devetnaestostoljetnoj europskoj pripovjednoj prozi.

Novakovo umještanje prostora Podgorja nalazi odjelite pripovjedne

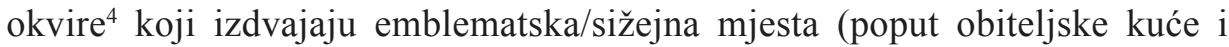
unajmljena "stanovanja", malogradske četvrti i metropolskoga predgrađa, trgovačkog i ribarskoga broda, sudišta), ispisuju promjenljivu, složenu geopolitičku i društvenu pozadinu ili prizorište priče, te koji se orisuju prostorima izvedenim iz dinamike radnje i likova. Fenomen osiromašivanja podloge podgorskoga života obuhvaćen je u Podgorskim pripovijestima metonimijom ruševine, razvaljene kuće ili pripovijedanoga raskuća ${ }^{5}: " \ldots$ Podgorski je kraj mrtav i pust kao da ga je božja milost napustila..."; "...Otud dolaze sami prosjaci. A da gospodine, naš kraj je sami prosjak..." Naglasak na alternativnim konceptima prostornosti kao posljetku fantazije, aspiracija i kreativne imaginacije likova koja ne poznaje razgraničenja protežnog u glazbenoj umjetnosti (stvaralaštvo Zlatanića u Dva svijeta) i u prirodoslovnoj znanosti (raskrivanje tajne života pobuđeno Darwinovom teorijom evolucije u romanu Pavao Šegota) doprinosi razumijevanju značenja pripovijedanoga prostora u Novaka.

Novakovo pripovijedanje stoga zahvaća u učinke simboličkoga poretka na kojemu se pred kraj devetnaestoga stoljeća iscrtavaju povijesno i kulturno značenje Podvelebitskoga primorja. Povjesnicu različitih načina "zaposijedanja" izvornosti ili geografskoga okoliša toga mjesta Novak dopunjuje obnovom percepcije njegove naravne supstancije. U podlozi je autorove pripovjedne tvorbe topofilijski, afirmativan stav spram materijalnih i nematerijalnih vrjednota toga krajobraza. Poseban je značenjski naboj onaj senjskoga i podgorskoga predjela sjećanja, zavičajna i naraštajna memorija građanske obitelji, seoske zajednice, dioništva u hrvatskome rodu. No u artikulaciji podgorskoga prostora Novak očituje i negativne evokacije koje

\footnotetext{
${ }^{4}$ M. L. RYAN, 2009, 440 .

${ }^{5} \mathrm{~V}$. NOVAK, 1933, 28, 84.
} 
vezanost za malogradsko mjesto obilježeno izvanjskim geografskim poretkom ostavlja u postupcima likova. Među njima, primjerice, razabire uskogrudnost, pasivnost i predrasude spram nepoznatoga kao one značajke koje imaju trajni zaprječujući učinak na samopredočivanje, to jest značajke koje generiraju identitetske "autostereotipe"6. Tako obuhvatna Novakova pripovjedna prozopografija Podgorja otvorit će stoga put i "topofobijskoj tematici književnosti"7 za kakvom će se povesti i modernist Milutin Cihlar Nehajev u romanu Bijeg: Povijest jednog našeg čovjeka (1909).

Simbolični poredci hrvatske kulture, književnosti i politike devetnaestoga stoljeća posljedovali su i određene stereotipije u pokušajima oblikovanja stabilnoga nacionalnog identiteta. Pripovjedna strategija koja podgorski značenjski krug tvori dinamičnim dijelom nepostojane cjeline, a ne statičnim modelom u malom ondašnjih hrvatskih prilika upisuje se u "kroatocentričnu imagologiju i stereotipiju kakvu su u hrvatskoj književnosti pronosili Matoš svojom poetikom "krajolika kao simbola nacionalne povijesti i identiteta u hrvatskoj književnosti" i Starčević u politici"8. No i simbolika i stereotipija identitetskoga diskursa vezanog za ideju "utopijskoga južnoslavizma"9 zastupljena je u pripovjednome vidokrugu Vjenceslava Novaka, osobito u romanima Pod Nehajem i Posljednji Stipančići.

Imagološko osvjetljivanje identitetske različitosti Podgorja u "razlomljenoj topografiji" Hrvatske ${ }^{10}$ započinje od njegova onomastičkoga gradiva:podgorskieponimi uromanimai pripovijestima (Podgorskepripovijesti, 1889) zaživljuju kao pripovjedne nadopune, varijable ovjerovljenomu govoru o ljudima i običajima toga podneblja. Zastupajući imagologiju koja je "začudna i antistereotipna"11 u odnosu na vrijedeća, izvanjska prostorna imenovanja, Novak otkriva svojevrsni podgorski podtekst kojem je ponovno zadobivena prostornost važno identitetsko obilježje.

U hrvatskoj umjetničkoj književnosti dotad vidljivo jedino kroz stilsku ornamentiku povijesne proze protorealizma Šenoe ( $\breve{C u v a j ~ s e ~ s e n j s k e ~ r u k e, ~}$ 1875), Podgorje se u Novakovoj inačici Raumromana pretvara u izvanmatični hrvatski prostor zahvaćen učestalim geopolitičkim razdiobama i ugrađen u

\footnotetext{
${ }^{6}$ D. ORAIĆ TOLIĆ, 2006, 29.

${ }^{7}$ S. GRGAS, 2014, 54.

${ }^{8}$ D. ORAIĆ TOLIĆ, 2006, 38-39.

${ }^{9}$ D. ORAIĆ TOLIĆ, 2006, 29.

${ }^{10} \mathrm{~S}$. GRGAS, 2014, 62.

${ }^{11}$ D. ORAIĆ TOLIĆ, 2006, 34.

${ }^{12}$ R.D. SACK, 1986, 54.
} 
značenjski kontekst kolonijalnoga narativa, to jest kontekst "dominantne teritorijalnosti"12 Austrijskoga Carstva. Procesi razgradnje izvorne cjelovitosti Senja s Podvelebitskim primorjem na tragu rečenih imenovanja i razgraničenja između, primjerice, slobodnoga kraljevskoga grada Senja i Vojne krajine sredinom devetnaestoga stoljeća (Pod Nehajem, 1894) dopisuju nove značenjske slojeve pripovjednomu prostoru Podgorja. Kruženjem slika primorskog ambijenta, senjskih veduta i marina, svetojurskog i klenovačkog uzmorja (Podgorka, 1894), te mijenama pounutarnjenoga krajolika likova (uzmaha bure, fantazma pobuđenih u dodiru s elementom, morem i zvjezdanim nebom u romanima Pavao Šegota /1888/, Posljednji Stipančići /1899/, Dva svijeta /1901/, Tito Dorčić /1906/) bilježi se sraz predodžaba o zakutnomu mjestu ograničenom na administrativne jedinice-općine Krajinske kumpanije na rubu Europe, s idejama pripadnosti zavičajnome Podgorju kao odvjetku hrvatske narodnosne ideje. Planina Velebit na Novakovu pripovjednomu zemljovidu istodobno obdržava simboliku istrajnosti narodnoga bića u "staromu gnijezdu prostrtu tvrdim kamenom"13 ali i označuje demarkacijsku crtu devetnaestostoljetnoga Podgorja prema drugoj Hrvatskoj i širem europskom obzoru: "...Kolika razlika u tihom životu siromašnoga Podgorja i u tom vrtlogu neslućenih ljudi!...Onamo shvaćanje prirode i čovjeka u predsudama po pjesmi i priči, što se rađa kraj siromašna ognjišta, a ovdje duh ljudski na svom vrhuncu, bogatstvo, znanost, umjetnost, prosvjeta..." ${ }^{14}$

Novak pripovjedno konkretizira partikularnost mjesta a njegov je pripovjedni podgorski prostor polimorfan kada mu prilaže mnogostruke sadržaje lokalne zbilje i realnoga prostor-vremena. Književnim će sredstvima u pripovjednim sastavcima modulirati identifikacijske točke zajednice (povjesnicu senjskih patricija i snaženje građanskoga staleža; podgorska "plemena" i njihove suce-starješine, Gornjaše-Bunjevce i Primorce, seoske savjete-"honoracije", "prosjačiju" uime preživljenja, pučki humor i praznovjericu) odričući u svojoj reprezentaciji kulturni stereotip hrvatske provincije unutar Habsburške Carevine. Prijelazi iz zatvorenoga prostora urbanoga Senja u velegradska središta europskoga kontinenta kao i otvorene, neizvjesne putanje podgorskih putnika-prosjaka čine pripovjednu okosnicu Novakove projekcije o prostoru pripadnosti. On nastaje orisivanjem mjesta Podgorja u svekolikome prostoru građanske Hrvatske i Europe kroza prizmu "malenosti" i "periferije".

${ }^{13}$ V. NOVAK, 1931, 10.

${ }^{14}$ V. NOVAK, 1931, 133. 
Proizvoljno tumačenje tih pojmova, izvanknjiževnih konstrukata za proizvodnju razlike u društvenim značajevima unutar kolektiviteta, trajno narušavaju osobni integritet pripadnika zajednice budući da se njihovo djelovanje kontinuirano podvrgava jednoj društvenoj svrsi (obrazovanju do promaknuća na staleškoj ljestvici i društvenoga priznanja, ili pak obvezi ustezanja od braka na određeni rok za stalna beriva i sigurnu mirovinu "financa" (udomaćeno "žbira"), nadstražara u carskoj službi predstavljenih u romanu Podgorka (1894). Pojedinačni uspjeh pripadnika zajednice Novak mjeri brzinom premošćivanja udaljenosti od podgorske provincije do središta, to jest pokušajima samoostvarivanja u drugomu okružju. U Novakovoj pripovjednoj konfiguraciji napuštanje ishodišnog okoliša donosi rizik obesnaživanja vlastita značaja.

Grgasovu postavku da je "...Umjesto usustavljenog prostora u kojemu je razvidna određena hijerarhija 'dominantne metafore', hrvatski spacijalni imaginarij jednostavno nabrajalački a da njegove prostorne sastavnice nisu konfigurirane, što se najbolje vidi kada pojam spacijalnog imaginarija povežemo s pitanjem regionalizma (...) te da regija "...nije izdvojen entitet, nego je uvijek postavljena u odnos s drugim mjestima i prostorima, odnosno regija uvijek na ovaj ili onaj način implicira nacionalni teritorij..." ${ }^{15}$, u Novakovu primjeru možemo tek djelomice potvrditi budući da mu u zahvaćanju podgorskoga krajolika nije stran stilotvorni način adicije i varijacije iz kataloga pojedinačnih slika, poput "kamena krša" i "glave/starca Velebita", ali će autor taj spregnuti, stiješnjeni okoliš otvoren moru, s izvanjskim pridjevcima regionalnoga, pokrajinskoga i perifernog ("ovako jadolika kraja nema na široko i na daleko, a za to valja i bolje zasukati rukave, da se pridignemo"16) iskušavati kao samosvojno mjesto pripadanja: "Ovdje se rađaju ljudi-pjesnici, ne oni velikani pjesnici. Ovi su ljudi mali obični ljudi kojima se bistra pamet rado gubi u šarovitom i jakom svijetlu bujne fantazije. Ukratko, ovi su ljudi nepraktičnjaci: kad ih izda jedna strana, ne umiju se obratiti na drugu..."17

Pod Nehajem (1892) iscrtava obrise dinamiziranoga pripovjednoga prostora kojim Novak odriče jednoznačne i hipostazirane predodžbe kolektiviteta, prije svega prikazbom istrajne borbe za samoodrživost senjskih trgovačkih obitelji Ivelića i Martinića i prilagodbu tranzicijskim prilikama pripadnika stare patricijske obitelji, te znakovitim imenovanjima - slom

\footnotetext{
${ }^{15}$ S. GRGAS, 2014, 58 .

${ }^{16}$ V. NOVAK, 1932, 89.

${ }^{17}$ V. NOVAK, 1932, 38.
} 
jednoga načina života grada i njegovih ljudi anticipira se stradanjem broda znakovita imena Pluto na obalama zapadne Italije.

U Posljednjim Stipančićima (1899) Senj postaje locusom europske periferije zahvaćen povijesnom mijenom i padom značaja od 1820-ih kada kao slobodni kraljevski grad živi od trgovine, do vremena kada mu položaj utvrđuju gospodarsko-političke mjere za granično područje Vojne krajine. Stilskom figurom sinegdohe i prodajom broda Valpurga, jedinoga preostaloga dijela obiteljske pokretne imovine Stipančićevih, Novak podcrtava dokinuće identitetskoga uporišta za postupke likova. Povratkom Jurja Stipančića u rodni grad po okončanju studija ("Moj je prijatelj mislio da je svijetu došao sudnji dan..."18) aktivira se opozicija vanjskoga svijeta i sužene podloge života na domaćim stranama. Grad zahvaćen burom postaje više od razdjelnice primorske i kontinentalne velegradske vedute, i simbol uzmaha nevolja za Stipančiće nakon očeve smrti. Prijelazom iz amblematskoga prostora sjećanja-rodne kuće Stipančićevih u klaustrofobični prostor jedne od najstarijih gradskih kuća pripadne Valpurginoj obitelji, Lucijin pogled u "slobodan i otvoren svijet $\mathrm{u}$ koji će se dići iz tog tamnog, mrtvog stanovanja"19 izjednačuje reprezentaciju pojmovno podijeljena prostora s raskolom u tvorbi pojedinčeva identiteta.

Liminalni ili rubni položaj Senja u Posljednjim Stipančićima ujedno je i vrijednosna odrednica za hrvatski prostor udaljen od jezgra zbivanja značajnih za život nacionalnoga korpusa ("...Ne dopiru do njih glasovi o narodnome jedinstvu..." ${ }^{20}$ ) jer Novak u hrvatski identitetski diskurs sustavno ugrađuje sve kontingencije tumačenja i poraba njegovih protežnih posebnosti. Stiješnjeni između društvene prinude i vlastite pobude, dionici toga prostora obilježena dvojstvom domaćeg i tuđinskog, vojnog i civilnog, hrvatskog i talijanskoga segmenta zakinuti su obuhvatiti cjelinu narodnosnoga bića: dok građani traže od dvojice poslanika u Požunskome saboru povrat izgubljenih prava slobodnog trgovanja i ukidanje vojne jurisdikcije, gospićka vojna uprava od gradonačelnika Tršćanina Benettija zahtijeva tek poćudan izbor poslanika koji će zadržati postojeće stanje stvari ${ }^{21}$. Zastrti duh od šire zajednice otuđena lokalnoga puka povodi se za načelom što ga Ivo Frangešnaziva "municipalnim partikularizmom"22 a Novak tumači kao "...nerazumijevanje za one izvan gradskih zidova: onog što

\footnotetext{
${ }^{18}$ V. NOVAK, 1964, 163.

${ }^{19}$ V. NOVAK, 1964, 167.

${ }^{20}$ V. NOVAK, 1964, 85.

${ }^{21}$ V. NOVAK, 1964, 159.

${ }^{22}$ I. FRANGEŠ, 1987, 203.
} 
je dolazilo s Vratnika bio je Bunjevac ili Vlah - tuđ čovjek s kojim izim trgovine nemaju nikakvog zajedničkog interesa..." 23

Neodredljivost vlastita mjesta pripadnosti u obuhvatu prostora junaka Novakovih romana iz senjskoga i podgorskoga života proistječe iz baštinjenih uvjerenja o strogoj vrijednosnoj razdjelnici između metropolskog i provincijskog. Iz sfere provincijskog likovi projiciraju svoje želje za nedosegnutim i neodređenim (Lucija Stipančić), a povratak u djelokrug provincije iznevjeruje očekivanja (Amadej Zlatanić, Dva svijeta). Dvojbe oko utvrđivanja pripadnosti izvornome krajoliku čine pripovjednu strukturu europskoga realističkoga romana na prijelomu 19. i 20. stoljeća. Novak tvori katalog pojmova i prispodoba vezanih za areal jugoistoka Europe i hrvatski mikroprostor Podgorja ne bi li ih kritički razglobio i u duhu poetike modernizma potaknuo emancipaciju od rečenoga pojmovnoga naslijeđa.

Iz prosudbe kritičara o nedovršenosti i nedorečenosti pripovjednoga postupka Novaka koji, premda "...smatrao se realistom nije pratio evropskih književnosti svoga vremena, niti se toliko uputio u filozofske i društvene nauke da bi mogao stvoriti potpuno određen i cjelovit nazor na svijet "... istodobno ishodi tvrdnja da je Novak bio "jedan od onih pisaca koji su vidljivo napredovali u svojem stilotvornom obuhvatu od realista pozitivista, darvinista, i autora sklona misticizmu i fatalizmu"24. Šicel govori o Novaku autoru neizgrađene i u suštini kontradiktorne filozofije ${ }^{25}$, no u njegovu umjetničkome protuslovlju prepoznajemo doista svojstvo modernističke poetike u nastajanju. Nemec izdvaja Novaka "...najvećim eksperimentatorom i inovatorom od svih naših realista..." koga "...njegov naglašen interes za psihologiju i sudbinu pojedinca, njegova smjela kompozicijska rješenja, pokušaji multiperspektivnog pripovijedanja vezuju za praksu moderne..."26. Ako se neodredljivost i otvorenost Novakovih umjetničkih strategija i ne mogu nazvati programatskima, hrvatski identitetski diskurs svakako prisvaja njihovu označujuću modernističku antitetičnost.

Značenje hrvatske provincije u Novakovim Posljednjim Stipančićima ne otkriva se kao posebnost urbanoga senjskoga locusa, već kao generičko obilježje hrvatskoga mjesta u povijesnome i geopolitičkome kontekstu. Prostor romana oblikuje se kontrastiranjem precizne topografije ranodevetnaestostoljetnoga

\footnotetext{
${ }^{23}$ V. NOVAK, 1964, 109-110.

${ }^{24} \mathrm{~V}$. NOVAK, $1964,16-19$.

${ }^{25}$ M. ŠICEL, 1979, 68.

${ }^{26}$ K. NEMEC, 1995, 237-238.
} 
Senja i panoramskih prohoda europskim središtima. Izlazak iz naravna okoliša što prvotno oblikuje Novakova Tita Dorčića ("tek more i morska obala, njegovo rođeno tlo, njegova misao, njegovo čuvstvo" u svijet društvenosti ("škola je ostala vazda crna strana njegova života"27, Novak izlaže problem uspostave integriteta svojega protagonista. U tomu romanu podjela na metropolu i periferiju (u katalogu slika poput "senjske doline podno Vratnika" i "plavetnoga mora i nedalekih otoka i sve obale"28 nasušnih za tradiciju ribarstva u rukama Dorčića, s pridjevkom Ribarića/"tekovine što su je Dorčići uzajmili od prirode" 29 , proistekla iz razdiobe političke i gospodarske moći na prostoru ondašnje Europe, pojačana je elipsama u fikcionalnoj konfiguraciji širega hrvatskoga prostora. Prostornom elipsom aludira se na privremenu promjenu dinamike protagonista u smjeru Senj-Beč. Novak supostavlja bečko velegradsko iskustvo Tita Dorčića s nepotpunim prostornim koordinatamatoponimima hrvatskih mjesta njegova službovanja, označenima kao V., P. i O.. Prozopografije izvorišnog mjesta ovdje obuimaju ambijent mora i brodovlja u slikama zaustavljenoga kretanja "...Na pučini je bio velik jedrenjak s razapetim jedrima; Činilo se kao da se stalno smirio na jednoj točki u kanalu..." ${ }^{\text {"30 }}$, ili su projekcije o preuzimanju načina naprednoga svijeta i željeznicom KarlovacSenj preobraženoga grada i okolice. Lokalni kolorit marine piscatorie u Titu Dorčiću pridaju mjesnome govoru pripadni nazivi dijelova ribarske opreme i postupaka (nevera, svjećarica, lučar, draga, šaranjić, grug, gružnjak, ubotnica).

Tito Dorčić, i prema svojoj žanrovskoj strukturi roman s tezom, razlaže Lamarckovu descendantnu teoriju (teorije tla i naslijeđa što ih biskupu Ožegoviću tumači ravnatelj Sabljak: "...Vrlo rijetko mogu da svladaju u sebi prirođenu surovost svoga podrijetla, nasilni su prema nižima i uza to do smiješnosti tašti na svoje znanje ili čast.." ${ }^{31}$ i Darwinovu selekciju kao načelo društvenoga razvitka. Nasljedna teorija o urođenoj surovosti i uskogrudnosti nižih staleža i obrazovanju odabranih dovodi se u svezu s hrvatskim prilikama čiju poboljšicu Sabljak vidi kao postupni prijelaz iz niže u višu kulturu i pregnućem darovitih izdanaka drugih staleža, odvraćajući tako nakanu Andrije Dorčića da svoga jedinca "... otme onomu što je u njegovu krv uživjelo nasljedstvom prenašanim kroz stotine godina od jedne generacije na drugu..." ${ }^{32}$.

\footnotetext{
${ }^{27}$ V. NOVAK, 1964, 167.

${ }^{28}$ V. NOVAK, 1964, 156.

${ }^{29}$ V. NOVAK, 1964, 183.

${ }^{30}$ V. NOVAK, 1964, 169.

${ }^{31}$ V. NOVAK, 1964, 220.

${ }^{32}$ V. NOVAK, 1964, 221.
} 
Iskorak mjesnoga junaka iz primarnog okoliša problematizira procese prijelaza granica staleških podjela i s njima povezanu etiologiju društvenoga uspjeha kakve nalazimo u europskome realističkome romanu kasnoga devetnaestoga stoljeća. Tragična zabluda Andrije Dorčića ishodi upravo iz pokušaja izjednačivanja sinovih odlika darovita djeteta mora s mjerljivim probicima njegove staleške tranzicije na društvenoj ljestvici. Tajnu svoje ribarske vještine iskazanu riječima "To je u meni a da ne znam kako, $i$ ja se tim služim a da opet ne znam kako (...) Sve ima svoju dušu...i nauka i trgovina i zanat i ribarija...sve... Tko pogodi tu dušu i zna je shvatiti, taj postane majstor, a onaj drugi ostane šegrt do svoje smrti"133 prenosi Tito Dorčić svojemu profesoru fizike i filozofske propedeutike Nijemcu Wolffu upoznajući ga s ovdašnjim ribolovnim običajima. Dorčićev iskaz neizravno ocrtava prostor pripadnosti, nedjeljivu vrijednost duha mjesta (genius loci) i njegovih ljudi.

Odnos Regine i Tita, u kojem rascjep između naravnog osjećaja pripadnosti zajednici i stečena društvena običaja Drugosti dosiže svoj uzmah, Novak tumači antitezom visoke i niske kulture, sociologijskim stereotipom iz znanstvenoga kategorijalnog aparata kasnoga devetnaestoga stoljeća: "... skobila se visokom kulturom oplemenjena ljudska duša s nekulturom čovjeka koji je po baštini iza predaka i po prilikama uzgoja ostao pored svih svojih navika u niskoj sferi priprostosti što bi gdjekada prelazila u surovost..." ${ }^{34}$ Dorčićeva samosvijest narušena stalnim zakrivanjem istine o sebi prerasta u nekovrsni identitetski simulakrum. Slikajući sredstvima modernističkoga stilskoga kompleksa strah koji je "postao glavni osjećaj Titova duševna života, strah uvećan vjerovanjem u mistične strane religije pomiješane s predsudama što oživljuju do zgoljnih činjenica sve bajke pučke fantazije. U toj religioznosti polukulturnoga čovjeka vidio je u onoj službenoj zabludi tek čin radi kojeg mora da ga progoni duh čovjeka koji je njegovom sukrivnjom pravedan završio sramotnom smrću na vješalima..." ${ }^{35}$, Novak svakako nadilazi pojmovni obrazac sraza kultura kao jedan od načina utvrđivanja granica prostora duha. Nesigurno tlo javnoga djelovanja Dorčića pristava i suca nedostojno zamjenjuje njegovo "pravo tlo u koje bijaše pustio duboko svoje korijenje moj život da upije iz njega snagu i radost"36, a iz kojega su ga roditeljskom voljom prenijeli u tuđe, uskrativši mu pravo na puninu života. U semantičkoj igri imenskim oblicima

\footnotetext{
${ }^{33}$ V. NOVAK, 1964, 195-196.

${ }^{34}$ V. NOVAK, 1964, 280.

${ }^{35}$ V. NOVAK, 1964, 306.

${ }^{36}$ V. NOVAK, 1964, 313.
} 
"moje pravo tlo" i "moje pravo" Dorčićeva solilokvija iscrpljuje se posljednja obrana njegova integriteta.

Polazište Novakova romana Dva svijeta (1901) neimenovani je primorski grad čija fragmentarna topografija podjeća na senjske vedute, a iz čije malogradske sredine ponikao je daroviti glazbenik Amadej Zlatanić. Umjetničko poslanje u glazbi koja je sinkretična i univerzalna prividno ga odrješuje ograničenja prostorne protege - iz pridanih vrijednosnih obrazaca periferije razvija se u njega autostereotip nečinjenja i malodušja pobuđen osjećajem pripadnosti malome narodu.

Novakov lik domaćega primorskoga sina, glazbenika Amadeja Zlatanića, i svojim umjetničkim iskazom svjedoči o kontrapunktu pojmova bliskog i dalekog, vidljivog/protežnog i pomišljenog riječima "...Naš je život beskonačna disonanca, prekinuta samo gdjekada kratkim horizontalnim akordom (...) U sebi i oko sebe osjeća dva svijeta. Drugi se svijet opire prvomu, promjenljiv je i nepojmljiv u svojoj nedosljednosti. ${ }^{37}$ Samorefleksija Novakova pripovjedna subjekta o tragu što ga u svijesti ostavlja diskrepancija u kulturnome razvitku i afirmaciji hrvatskih ljepoduha u krilu moderne Europe navezana je na situaciju u kojoj Zlatanić odriče vlastito ime i autorski identitet za kompoziciju koju šalje u Berlin ne bi li unaprijedio svoje prilike: "Prodao sam svoje ime, ponos svoje duše, i ostao sam prazan kao od proste građe posuda, iz koje su istočili plemenitu tekućinu, Tup, tup, tup."38 Hrvatsko mjesto u ovome romanu predstavlja se u svojem punome spektru što ga čine šuma, ravnica i sunčani primorski okoliš, u zamišljenom, sveprožimajućemu krajoliku čiji su predjeli "među nebom i među zemljom", i u kojem se miješaju tonovi vlastite Himne ljubavi i Beethovenovih fuga.

Kada povratkom u domaju Zlatanić iskazuje ganuće i promišlja o slavi na domaćim stranama, Novak će literarnim toposima iz registra stvorena prostora umjetnosti (Preradovićev stih "Primi cjelov, zemljo mila"39 ukazati na protagonista koji s prostorne i vremenske distance nije u stanju razabrati realne obrise izmijenjena lokalnog okoliša, te mu je kao otuđenomu povratniku zavičajni krajolik postao tek umjetničko-stilski ornament.

Uz promišljenu reprezentaciju podgorskoga prostora koja funkcionira kao istovrijednica razsredištenomu subjektu, Novak prilaže pripovjedni sadržaj za hrvatski identitetski diskurs u nastajanju. Nemec naglašuje kako

\footnotetext{
${ }^{37}$ V. NOVAK, 1931, 169.

${ }^{38} \mathrm{~V}$. NOVAK, 1931, 182.

${ }^{39} \mathrm{~V}$. NOVAK, 1931, 101-103.
} 
"... regionalizam u Novakovu primjeru ne znači zatvaranje u uske okvire i provincijalizaciju problematike (...) Ali regionalno je uvijek prevladano univerzalnom tematikom, a kroz pojedinačne sudbine probija se cjelovita $i$ neuljepšana priča o hrvatskom čovjeku u prošlom stoljeću..."40

Geografija primorskoga ruba na uključuje jedino granicu nego i otvorenost moru - dvojna je narav toga označujućega međuprostora važnog za proces razgraničenja identiteta pojedinca i kolektiva. Likovi zatečeni sobom kao djelujućim subjektima, svojim hibridnim identitetskim statusom i pretapanjem prostornokulturnih orijentira grade poseban osjećaj pripadnosti u Novakovu pripovjedno-stilskom obliku prijevoda jednoga načina strukturiranja svojeg identiteta u novi. Zastanak priče na rubnome mjestu pripovjedni je hijatus, poziv da se preispitaju razmjeri otuđenja u diobi ljudske zavičajnosti na domaće i izvanjsko. Fikcionalni subjekti u Novakovim romanima i pripovijestima iz podgorskoga života nisu stoga samo reprezentativni predstavnici svoje društvene skupine, već problematični subjekti izmaknute zavičajnosti.

Novakovo pripovjedno podgorsko mjesto obuhvaća prostornost mora i obale koju konceptualizira svezama s čovjekom konkretnoga fragmenta hrvatskoga podneblja, u rasponu od kinetičkih slika Dorčićeve simbioze s morem uza "svoju" grebenastu obalu, do izlaska u šir svjetskih mora u odlomcima o rutama jedrenjaka u vlasništvu senjskih trgovaca (Posljednji Stipančići), te stradanjima brodovlja i mornara na koja su navezane sudbine obitelji na podgorskome kraju (Podgorske pripovijesti). Na djelu je pripovjedni otklon od spacijalne predodžbe mora kao "identitetske univerzalije" i "sublimnog prostora koji partikularizira ljudske kolektivitete"41 i prepoznavanje procesa koji destabiliziraju umještenost ili "ukorijenjenost u navlastitomu dijelu hrvatskoga spacija"42.

Novak oblikuje spacijalni imaginarij hrvatskoga realističkoga romana iz senjskog i podgorskoga života ne odjeljujući ga od njegova "velegradskoga ambijenta" te raznorodne vidove Matoševe "hrvatske okolice"43 amalgamira u pripovijedanu prostornost koja se kao protežna i psihološka kategorija ugrađuje $\mathrm{u}$ autorski obilježen identitetski diskurs. Za Novaka takav koncept prostornosti ili mnogoliki prostorni način postaje punovrijedni tematski kompleks u pripovjednoj prozi na prijelomu stilskih formacija realizma i modernizma.

\footnotetext{
${ }^{40}$ K. NEMEC, 1995, 230.

${ }^{41}$ S. GRGAS, 2014, 61-62.

${ }^{42}$ S. GRGAS, 2014, 63.

${ }^{43}$ D. ORAIĆ TOLIĆ, 2006, 34.
} 
Literatura

Ivo FRANGEŠ, Povijest hrvatske književnosti, Zagreb, 1987, 203.

Ivo FRANGEŠ, Književnost hrvatskog realizma u evropskom kontekstu, u A. Flaker, Hrvatska književnost u evropskom kontekstu, Zagreb, 1978.

Stipe GRGAS, O hrvatskome spacijalnom imaginariju, u: Lana Molvarec (ur.) Mjesto, granica, identitet-Prostor u hrvatskoj književnosti i kulturi, Zagreb, 2014, 4967.

John HILLIS MILLER, Topographies, Stanford University Press, Stanford, 1995.

Krešimir NEMEC, Povijest hrvatskog romana od početaka do kraja 19. stoljeća, Zagreb, 1995, 227-230.

Vjenceslav NOVAK, Djela, Pet stoljeća hrvatske književnosti, Knjige 57 (Pripovijesti) Lutrijašica; Što je krivo; Posljednji Stipančići) i 58 (Pripovijesti; Tito Dorčić), Zagreb, 1964.

Vjenceslav NOVAK, Dva svijeta (1901), Zagreb, 1932.

Vjenceslav NOVAK, Pavao Šegota (1888), Zagreb, 1931.

Vjenceslav NOVAK, Podgorske pripovijesti (1888), Zagreb, 1933.

Vjenceslav NOVAK, Podgorka (1894), Zagreb, 1932.

Vjenceslav NOVAK, Pod Nehajem (1892), Zagreb, 1931.

Dubravka ORAIĆ TOLIĆ - Ernö Kulesár SZABÓ, Zbornik Kulturni stereotipi/ Koncepti identiteta u srednjeuropskim književnostima, Zagreb, 2006.

Marie LAURE RYAN, Space, u: Peter HUHN (ur.), Handbook of Narratology, de Gruyter, Berlin, 2009, 440-433.

Robert David SACK, Human Territoriality, Its Theory and History, Cambridge University Press, Cambridge, 1986.

Miroslav ŠICEL, Pregled novije hrvatske književnosti, Zagreb, 1979. 


\section{PODGORJE IN THE NARRATIVE MODEL OF VJENCESLAV NOVAK}

\section{Summary}

The paper analyses the methods of literary articulation of Podgorje in the narrative prose of Vjenceslav Novak (Pavao Šegota, Pod Nehajem, Posljednji Stipančići, Tito Dorčić, Dva svijeta). Podgorje was not noted as an idealised home region on the edge of the Austrian Empire, but was transformed into a poetic tool of the questioning of the personal and collective identity of the participants of this region, whose marginal position is also considered as a consequence of the conflicting and non-existent parts of Croatian individuality. A move in the analysis of the place of the story from the centre to the edge, as well as the transitions between the semantic fields of the metropolis and the provinces, make up a narrative creation with which Novak enriches his realist poetics, depicting the dimensions of political and class transitions in the separated, tucked away Croatian place, a subject outside of central European literary production. With his fictional configuration of the area, Novak aligns the division at the centre and periphery resulting from the distribution of the political and economic powers of $19^{\text {th }}$ century Europe, as well as a valuable dividing line. Doubts about the affiliation of the original landscape make up a narrative structure of a European realist novel at the turn of the $19^{\text {th }}-20^{\text {th }}$ centuries. The narrative topography of Vjenceslav Novak extends the Croatian environment to the landscape of a smaller littoral town and the Podvelebit coast whose original extensibility and diversity add meanings developed from the tension in the interpretation of the relationship of a centre and a province. Novak's narrative excursions about the features of Podgorje are interwoven with the common references of the geopolitical idea of a European province, which are distributed over this peripheral area.

Keywords: Vjenceslav Novak, narrative area, Podgorje, poetics, centre, periphery 